\title{
The Correlation Between Vocabulary Mastery And Self Esteem On Students' Speaking Skill
}

\author{
Nurmala Dewi ${ }^{1}$, Jimmi ${ }^{2}$ \\ ${ }^{1}$ Akademi Bahasa Asing BSI Jakarta \\ nurmala.nmd@bsi.ac.id \\ ${ }^{2}$ Akademi Bahasa Asing BSI Jakarta \\ jimmi.jmm@bsi.ac.id
}

\begin{abstract}
The purpose of this research was to find out whether there is a significant correlations between vocabulary mastery and self esteem on students' speaking skill. The population of this study was $X$ grade students majoring in natural science at SMU 64 Jakarta Timur, while the sample was 60 students were chosen randomly from 3 classes. The writers used three instruments to gain the data : a vocabulary test, a speaking test, and a self esteem questionnaire. A quantitative analysis that included descriptive statistic and the correlation and regression analysis tests were conducted to answer the research hypotheses. The research results found that there is a significant simultaneous correlation between vocabulary mastery and self esteem on students' speaking skill. This finding has proved the views which are vocabulary as a main language component and self esteem as affective factor have contributions in developing learning language especially for speaking skill.
\end{abstract}

Key words : Vocabulary Mastery, Self Esteem, Speaking Skill

\section{INTRODUCTION}

In learning English, having proficiency merely about grammar, vocabulary or another component of language are not enough for being a successful learner. The important thing, he must be able to apply it in a fluently real communication. Further implementation, he can interact or participate appropriately with many people in the societies. Additionally, inevitable fact that speaking is dominantly used for communication in any aspects of our lives. Therefore, focusing on how to develop a communicative proficiency, specifically in speaking skill is a crucial option which should be considered nowadays.

However, speaking is one of the challenging skills for the most English language learners. It is one of productive skills which could be a parameter for someone in having a successful learning English. Likewise in the working world, the ability of English speaking will give an added value on someone's performance professionally. But it is not facile way for them to achieve a tittle as an eloquent speaker. As a general problem, a lot of people have taken studying English for many years whereas some of those obtained high grades in grammar or in English written tests, but in fact they are still unable to speak English well. It might that they could understand what they hear or what they read comprehensively but they still quite struggle how to express their mind orally.

In mastering English, especially speaking, the learners have to acquire either some language components as their technical knowledge to construct the language and the internal factors to support them in delivering it well. Vocabulary as one component of language knowledge is considered as the most essential elements to build a language. It has also been acknowledged that vocabulary knowledge is a good predictor of general language proficiency. Some studies have revealed that a large and rich vocabulary can improve learner's ability to communicate properly. Otherwise, the lack of vocabulary becomes a major problem in producing sentences, particularly for those students at the earlier levels. They do not have enough words which causes less resource to construct the sentences, even for basic utterancies. Further, by lack vocabulary might prevent them to speak fluently and become slow down in interaction, although they have quite confidence and enthusiastic in language learning.

Nevertheless, the writers found a fact that student whose adequate language proficiency on vocabulary or grammar, still have difficulty in speaking. This phenomenon indicates which there are internal factors might hold them to express the ideas. Self esteem is one of the internal factors that may indirectly influence the students' performances on handling the tasks particularly on speaking skill. It is one of psychology factors which reflects as a judgment of individuals' believes that they are worthy, competence and capable doing the tasks. Based on some previous researches, it seems that self esteem is regarded as impetus to initiate foreign language learning and it could affect students' performances in speaking. The student with high self esteem believes that he is quite confident and may be able to perform the speaking tasks successfully.

Besides the facts above, in learning English especially speaking, it should have a standard achievement that needs to be reached by the 
learners. Recently U.S Department of Education collaborated with foreign language learning associations from Asia and Europe countries such as Malaysia, China, Japan, Mexico, etc have developed an English learning guideline for English courses and schools in countries where English become a second or a foreign language (Standards for Foreign Language Learning in the $21^{\text {st }}$ Century : 2006). This standard is expected to be applied in ASEAN countries including in Indonesia. One of standards that should be achieved by English learners stated that "at the end of high school, students engage in conversations, provide and obtain information, express feelings and emotion, and exchange opinions". It seems that students in senior high school should attain an adequately communicative competence in those level societies. However in reality, apparently it is quite difficult to meet the standard. Likewise, it can be also seen for those students at SMU 64.

Based on the writers' observations, students speaking ability at SMU 64 Jakarta is very far from the standards which have been stipulated to be achieved by foreign language learners. This condition may due to their inadequate language component matters cause the speaking problem or it might due to their internal factors cause the inhabitation in speaking. Regarding to the facts and the descriptions above, therefore writers was interested to conduct a research regard to the correlation between students' vocabulary mastery and students' self-esteem on students' speaking skill at SMU 64 Jakarta Timur.

\subsection{Speaking Skill}

Learning speaking is a very complex task whereas the learners need to understand the nature and skills to be involved. As stated by Richard (2003 : 201) that the different genres and different contexts need different ways and skills. So, learning to speak a foreign language requires more than knowing its grammatical and semantic rules. Learners must also comprehend the knowledge of how to use the language in different contexts. In other words, the learners do not only know the element of languages such as, grammar, pronunciation, vocabulary, and so on, but also understand on when, why, and in what ways to produce language for many purposes. Richard added (2003: 204-206) that there are some factors affecting adult learners' oral communication. They are age or maturational constrains, aural medium, social cultural and affective factors. The affective factors which may influence in learning a foreign language are such as emotions, self-esteem, anxiety, empathy, attitude, and motivation. So in learning a language, the emotional factors are susceptible to human anxiety, which is associated with feeling of shyness, uneasiness, frustration, selfdoubt and so on.
Regarding to speaking, the issues which come up in the process are caused of some aspects; it can be related to their knowledge of the language, their social and cultural background and their personality on using the language itself. This view is claimed by Burns and Joyce's in Nunan (1999 : 231) stated that the problem in speaking may be due to cultural factors, linguistic factors, and psychological/ affective factors. From those aspects, affective factor which it related to the emotional factors will give the biggest contribution on students' barriers in speaking process and influence their performance in delivering the messages.

\subsection{Self Esteem}

Self esteem is one of affective factors which has got many attentions in affecting someone's achievement especially in academic performance. Self esteem is important because it influences people's choices and decisions. In other words, it is such a motivational function that people will take care of themselves, explore their full potential and persistently strive towards their goals and aspirations. Distinguishing definitions of self esteem refers to what matters that scholars pay attention to this concept . One of them stated by Rubio (2007 : 5 ) as follows :

Basically, self-esteem is a psychological and social phenomenon in which an individual evaluates his/her competence and own self according to some values, which may result in different emotional states, and which becomes developmentally stable but is still open to variation depending on personal circumstances.

According to Brown (1994 : 145 - 146), there are three general levels of self -esteem which described its multidimensionality. These three kinds of self esteem are possessed by everyone in a different level quality and could influence their performances in daily life. Firstly, general or global self-esteem is a general assessment that one makes of one's worth across different situation or overall appraisal. This is relatively stable in a mature adult, and it is resistant to change except by active and extended therapy. Secondly, situational or specific self-esteem refers to one's self- appraisal in particular life situation, such as social interaction, work, education, home, or certain relatively discretely defined traits, such as intelligence, communicative ability, athletic ability or personal traits like gregariousness, empathy, and flexibility. Thirdly, task self esteem related to particular tasks within specific situation. For example, within the educational domain task, self esteem might refer to one subject - matter area.

Throughout the history of language learning and teaching, many studies have been conducted to see the effects of self-esteem on students' performance. Most studies found that there is a significant correlation between the students self - esteem and 
their verbal performance (e.g. Adelaide Heyde in Brown, 1994; Kalanzadeh et al, 2013; Niki Maleki and Mohammadi, 2006)

Based on those findings, it can be assumed that selfesteem is a significant factor in the level of accomplishment of students' achievement especially in speaking. Students with high self-esteem most likely believe themselves to be significant and worthy individuals as well as capable of learning a language.

\subsection{Vocabulary Mastery}

Vocabulary is a basic component of a language which plays a major role in both comprehension and production skills. Students are able to speak and write comprehensively with possessing adequate knowledge of vocabulary. Hence, in the beginning level of learning, they devote a lot of time to acquire the words. The learners have to know the meaning from the general one to the deeper and sophisticated one. Moreover, as their language proficiency develops, learners are not only knowing about the meaning and the form of words, but also knowing how to use it in any contexts and situations properly. There are many aspects involved on the words and level of degrees of knowing is varied as well. To develop word knowledge and understand how to apply words properly, there are three basic criteria of knowing a word : knowing its form, its meaning and its use (Nation, 2001). The first, form aspect, it is related to the word parts which make up the word, spoken form and written form. The second, the meaning aspect, it is concerned to the connection between the form and its meaning, the concept and reference which word have variety of meaning, and the association which means the semantic relationships between words, such as synonymy and antonym. And the third, the use aspect, it is about the grammatical function of the words, collocation, and constrain on use which when, where and how often can we use the word.

Mastering vocabulary and being smart on how to employ it properly is crucial for learners of a foreign language to develop their speaking skill. By having many stocks of word, students could also more comprehend about the conversation, give a quicker response in a chat or maybe speak fluently in some kinds of topic. Without sufficient vocabulary, one cannot communicate effectively or

express his ideas in both oral and written form perfectly (Cameron, 2001).

Many studies have shown that a large and rich vocabulary can improve learner's ability to communicate. One of them is conducted by Nouralian et al (2013), which they investigated the influence of the vocabulary knowledge on intermediate EFL learners' speaking ability in Iran. The results of the study showed that the teaching vocabulary knowledge can improve speaking ability of EFL students. The study also revealed that the students were extremely satisfied with this approach. It gives them a better opportunity to improve their English speaking. So the teachers should set the appropriate period to help learners to fulfill their potential about preparing vocabulary knowledge for their speaking performance. The similar result of research was also found by Koizumi and In'nami (2013) in Japan which supported the contribution of vocabulary on speaking proficiency as well.

\section{METHOD OF THE RESEARCH}

The purpose of the research is to investigate the correlation between students' self esteem and students' vocabulary mastery on students speaking skill. The method of study is quantitative research, which applies correlation research. According to Frankel and Wallen (2007: 338) in a simple form, correlation research investigates the possibility of relationship between two variables, although investigations of more than two variables are common.

The population of this study was the students of tenth grade majoring in natural science. The reason for choosing this population is because of the problems mentioned previously emerged from most of these classes. Besides, the access and the condition of the school were available for conducting this research . Meanwhile, the sample of study derived from the certain amount of students in each classes of $\mathrm{X}$ grade. There are three classes of the tenth grade and each class consist of 36 students. The total sample was 60 students which is obtained 20 students in each class of tenth grade by using simple random sampling.

The data was collected from three instruments of the research ; vocabulary mastery was derived from

distributing self esteem questionnaire adopted from Rosenberg's questionnaire and the speaking test was conducted to have the speaking skill. Before the tests conducted, the writer carried out a tryout of the instruments to measure the validity and the reliability of the instruments. The data collected from instruments was computed by using SPSS 21. Before the data was analyzed, normality test and linearity test were applied in order to know whether the data are distributed normal and linear. Having done with these both tests, correlation and multiple regression techniques were used for the analysis. 


\section{RESULT AND DISCUSSION}

Table 1. Statistics Description of Variables

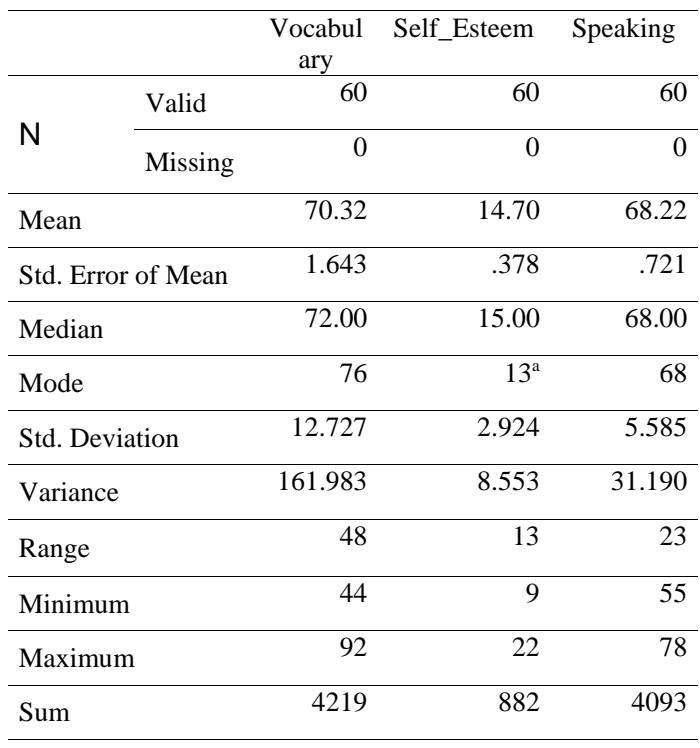

The data of this research would be presented in descriptive analysis and hypothetical analysis. Regarding to the statistic descriptive in table 1, it can be generally seen that the mean scores for three variables of speaking skill, vocabulary mastery and self esteem are in moderate category. The average score of speaking skill and vocabulary were 68,22 and 70.32. Apparently, both scores were lower than the standard English score (KKM score) 75, which is English minimum score should be reached by students at SMU 64. It was also showed that the range score for vocabulary (48) is larger than range score of speaking (23). It can be assumed that the diversity of students' ability in speaking is quite small compared to the diversity of students' ability in vocabulary. So that, even some students' vocabulary scores were very high but their speaking scores were not in the same level of proficiency.

Meanwhile the average score for students self esteem was 14.70 . This score is almost close to the normal standard of self esteem (15). It can be said that the level of students self esteem were in normal category as well, it is not very high or very low.

Table 2: The Relationship among the Variables Model Summary

\begin{tabular}{llccc}
\hline Model & R & R Square & $\begin{array}{c}\text { Adjusted R } \\
\text { Square }\end{array}$ & $\begin{array}{c}\text { Std. Error } \\
\text { of the } \\
\text { Estimate }\end{array}$ \\
\hline 1 & $\mathbf{. 6 4 1}^{\mathbf{a}}$ & $\mathbf{. 4 1 1}$ & .390 & 4.362 \\
\hline
\end{tabular}

Predictors: (Constant), Self_Esteem, Vocabulary
Table 3 : Testing of Significance of Multiple Regression ANOVA $^{a}$

\begin{tabular}{llllll}
\hline Model & $\begin{array}{l}\text { Sum of } \\
\text { Squares }\end{array}$ & df & $\begin{array}{l}\text { Mean } \\
\text { Square }\end{array}$ & F & Sig. \\
\hline Regression & 755.409 & 2 & 377.705 & $\mathbf{1 9 . 8 4 7}$ & $\mathbf{. 0 0 0}^{\mathbf{b}}$ \\
\hline $\begin{array}{l}\text { Residual } \\
\text { Total }\end{array}$ & 1084.774 & 57 & 19.031 & & \\
\hline a. Dependent Variable: Speaking & & & \\
b. Predictors: (Constant), Self_Esteem, Vocabulary &
\end{tabular}

Table 4: Testing of the Regression Line Equation

Coefficients $^{\mathrm{a}}$

\begin{tabular}{|c|c|c|c|c|c|}
\hline \multirow[t]{2}{*}{ Model } & $\begin{array}{l}\text { Unstanda } \\
\text { Coeffici }\end{array}$ & $\begin{array}{l}\text { dized } \\
\text { ents }\end{array}$ & $\begin{array}{l}\text { Standard } \\
\text { ized } \\
\text { Coeffici } \\
\text { ents } \\
\end{array}$ & $\mathrm{t}$ & \multirow[t]{2}{*}{ Sig. } \\
\hline & B & $\begin{array}{l}\text { Std. } \\
\text { Error }\end{array}$ & Beta & & \\
\hline (Constant) & 43.714 & 3.937 & & 11.104 & .000 \\
\hline vocabulary & .207 & .045 & .472 & 4.561 & .000 \\
\hline Self_Esteem & .676 & .198 & .354 & 3.419 & .001 \\
\hline
\end{tabular}

Related to the research hypothesis, the findings research found that all the three hypotheses accepted $\mathrm{H}_{1}$ and rejected $\mathrm{H}_{0}$. The discussion of analysis and hypotheses testing are described in detail as follows:

\section{The Correlation between Vocabulary Mastery $\left(X_{1}\right)$ and Speaking Skill (Y)}

The correlation coefficient $\left(r_{\mathrm{y} 1}\right)$ between vocabulary mastery and speaking skill was 0.538 . This indicates that the strength of relationship is moderate and positive. Even though the tendency of relationship in score showed is not very high, but it is still quite representative in its significance. The relationship score was not maximum result, it may be caused of the limitation of this study and also due to many factors influence the speaking skill. Referring to the theory, it is claimed that vocabulary is one of language component which very important in developing of speaking. Yet, vocabulary is not merely one aspects in contribution on speaking skill. A lot of others of internal factors and external factors influence students' performances in oral communication.

Based on coefficient table ( table 4), it was found that $\mathrm{p}$ value 0.000 was smaller than $\alpha 0.05$. and $\mathrm{t}$ test 4.561 was greater than $t$ table 2.002. It can be concluded that there is significant correlation between the vocabulary mastery and speaking skill. This result is in line with the finding research conducted by Nouralian et al (2013), it proved that vocabulary support the development of speaking skill.

2. The Correlation between Self Esteem $\left(\mathrm{X}_{2}\right)$ and Speaking Skill (Y) 
The correlation coefficient $\left(\mathrm{r}_{\mathrm{y} 2}\right)$ between self esteem and speaking skill was 0.442. Even though this correlation coefficient is still in moderate category and positive, but the value of correlation between self esteem and speaking is lower than the value of correlation between vocabulary and speaking (0.538) It indicates that the affective factors are not as much as linguistic factors in influencing the speaking skill. It may due to linguistic factors have directly relation in increasing language achievement rather than affective factors.

Reagrding to table 4, it was found that $\mathrm{p}$ value was 0.001 which is smaller than $\alpha 0.05$ and $t$ test 3.419 was greater than $\mathrm{t}$ table 2.002. Therefore, it can be summarized that there is significant correlation between self esteem and speaking skill controlling for vocabulary. The researches supported this view, one of them carried out by Kalanzadeh et all (2013). Their research finding found that the more successful learners regarding the oral communication had higher self - esteem than less successful ones in performing oral communication tasks. It was answer the main question raised in that study that there is a significant relationship between self - esteem and spoken fluency and classroom oral participation.

\section{The Correlation between Vocabulary Mastery $\left(X_{1}\right)$ and Self Esteem $\left(X_{2}\right)$ on Speaking Skill $(Y)$}

After analysis of the data, it can be seen on the table 1 , that the coefficient correlation or $\mathrm{R}$ was 0.641 . It indicates that the correlations among the variables are positive and moderate. Another finding, the coefficient determination or $\mathrm{R}^{2}$ was 0.411 . It means that vocabulary and self esteem give $41.1 \%$ contribution on speaking whereas $38.9 \%$ is determined by other factors such as grammar, pronunciation, etc

Concerning to Anova table, it revealed the overall correlation between vocabulary mastery and self esteem on speaking skill are significant. Based on the students' scores at SMU 64, most of students who have high scores in vocabulary and self esteem also tend to have high sores in speaking test. It was also found that some students who got high score in speaking used various words or high frequency vocabulary in expressing their ideas. Apparently, the words easily came up when they delivered the sentences. The significant correlation mentioned above, was correlated to the self esteem as well. It is definitely that self esteem will help student mentally to be more confident and believe that he is capable in learning English.

Furthermore, based on the coefficient table, the writers can set the linear regression equation showed as follows :

$$
\breve{Y}=43.714+0.207 \mathrm{X}_{1}+0.676 \mathrm{X}_{2}
$$

From the equation, it can be predicted the value of speaking skill based on the value of vocabulary and self esteem. For example, if the value of vocabulary and self esteem is 0 , the value of speaking is 43.714. Besides, based on the coefficient regression of $b$, it can be interpreted that one point of increase of vocabulary would result in 0.207 increase in speaking skill. While, one point of increase of self esteem would result in 0.676 increase in speaking skill. In other words, it can be said that vocabulary and self esteem will help students in increasing the ability of student's speaking skill.

All in all, those research findings above show that vocabulary and self esteem give contribution in developing of student's speaking skill. By having enough vocabulary the studenst have words to deliver their concepts, thoughts and minds. Yet, if the students do not have enough vocabulary, it does not mean they would be able to speak English well. It have to be supported by other factors, such as self esteem. By supporting good self esteem, the students will be sure and confident with their ability and do not hesitate to express their ideas in whatever condition is.

\section{CONCLUSION}

Regarding to the research finding, it can be concluded that the correlation between vocabulary mastery and self esteem on speaking skill are positive and significant. It means that vocabulary and self esteem have affect on helping students to improve their speaking skill. If vocabulary and self esteem increase, the students' speaking skill will increase too and vice versa. This finding has proven and strengthened the previous theory specifically for affective factor whereas self esteem is considered to language learning process particularly in improving speaking skill. Therefore, in supporting students to improve their speaking, the teachers should educate all factors which are not merely the cognitive factors but also the affective factors.

The implementation of the research, the teachers should help students to improve their speaking by identifying the problems which could be related to linguistic factors or internal factors. In term of linguistic factors, vocabulary as a basic component of the language has to been taught to the students with various techniques which make it easily to adopt. Besides the linguistic factors, the teachers should also be more aware on affective factors for instance self esteem which has been proved increasing students speaking skill.

\section{REFERENCES}

Aregu, Bekele Birhanie. (2013). Self-efficacy, selfesteem and gender as determinants of performance in speaking tasks : Journal of Media and Communication Studies Vol. 5(6), 
pp.64-71.

http://www.academicjournals.org/JMCS

Branden, Nathaniel. (1995). Six Pillar of Self Esteem. New York : Batam books.

Brown, H.Douglas.(2001).Teaching by principles :An interactive approach to language pedagogy. New York : Pearson Education Ltd.

Brown, H. Doughlas. (2000). Principles of Language Learning and Teaching. New York: Pearson Education.

Cameron, Lynn. (2001). Teaching language to young learners. UK : Cambridge University Press.

Coopersmith, S.(1967). The Antecendents of Self Esteem. San Francisco. CA.: W.H Freeman.

Fraenkel, Jack. R. \& William Norman E Walen. (2007). How to Design and Evaluate Research in Education. Mc. Graw-Hill.

HeathertonT, F., \& Polivy, J. (1991). Development and validation of a scale for measuring state self-esteem. Journal of Personality and Social Psychology, 60, 895-910.

Kalanzadeh, Gholam-Ali et al. (2013). The influence of EFL students' self-esteem onTheir speaking skills. The International Journal of Language Learning and Applied Linguistics World (IJLLALW) Vol. 2 (2), February 2013. p. 7683. Retrieved on March $1^{\text {st }}, 2015$ from www.languagelearningworld.org

Koizumi, Rie \& Yo’Innami. (2013). Vocabulary Knowledge and Speaking Proficiency among Second Language Learners from Novice to Intermediate Levels. Journal of Language Teaching and Research, Vol. 4, No. 5, pp. 900913. Finland: Academy Publisher Manufactured

Maleki,Niki, \& M. Mohammadi A. M. (2009). Selfesteem and Anxiety of Iranian EFL Learners in Oral Communication Tasks. Journal of linguistic studies, 2 (2).p. 47-54.
Murk, Christopher J. (2006). Self esteem research, theory and practice. New York: Springer Publishing Company.

National Standards in Foreign Language Education Project. (2006). Standards for Foreign Language Learning in the $21^{\text {st }}$ Century. United Stated: Allen Press.inc

Nation,I.S.P. (2001). Learning Vocabulary in another language. United Kingdom : Cambridge University Press.

Nunan, David. (1995). Language teaching methodology. Britain: Prentice Hill International.

Nunan, David. (1999). Second language teaching and learning. Boston: Heinle\&Heinle Publisher.

Richard, Jack C. (2003). Methodology in language teaching. Cambridge University Press.

Rubio, Fernando. (2007). Self-Esteem and Foreign Language Learning. Newcastle: Cambridge Scholars Publishing

Stern H.H.. (1986). Fundamental concepts of leanguage teaching. Oxford: Oxford University Press.

Ujang,.Suparman, (2010). Psycholinguistic : The theory of Language Acquisition. Bandung: Arfino Raya Press. 